\title{
Evaluasi Hasil Pelaksanaan Teknologi Modifikasi Cuaca di Jawa Barat Menggunakan Analisis Data Curah Hujan
}

\author{
Budi Harsoyo ${ }^{1}$, Untung Haryanto ${ }^{1}$, Tri Handoko Seto ${ }^{1}$, Sunu Tikno ${ }^{1}$, Tukiyat ${ }^{1}$, Samsul \\ Bahri $^{1}$
}

\section{PENDAHULUAN}

DAS Citarum terletak di Propinsi Jawa Barat, Indonesia. Dengan ketiga waduk kaskadenya yaitu Waduk Saguling, Cirata dan Jatiluhur, DAS Citarum mempunyai peranan yang sangat strategis karena mampu memberikan pasokan air bagi berbagai kebutuhan di daerah hilir. Aliran Sungai Citarum menjadi sumber pasokan bagi kebutuhan air irigasi, kebutuhan air baku bagi Perusahaan Daerah Air Minum (PDAM) di beberapa kabupaten di Jawa Barat dan DKI Jakarta serta untuk kawasan industri yang berada di wilayah Kota Jakarta dan sekitarnya. Selain memberikan pasokan air untuk berbagai kebutuhan di daerah hilir, aliran Sungai Citarum juga dimanfaatkan untuk Pembangkit Listrik Tenaga Air (PLTA) yang mampu menghasilkan energi listrik rata-rata sebesar 1.000 juta KWh per tahun.

Untuk mengantisipasi dan mengatasi kondisi defisit air saat musim kemarau di ketiga waduk tersebut, para pengelola waduk DAS Citarum, yaitu Perum Jasa Tirta II (Waduk Jatiluhur) PLTA Cirata (Waduk Cirata) dan PLTA Saguling (Waduk Saguling) kerap kali meminta jasa UPT Hujan Buatan BPPT untuk melakukan kegiatan modifikasi cuaca guna meningkatkan curah hujan di DAS Citarum. Terhitung sejak tahun 1980 hingga sekarang kegiatan modifikasi cuaca di DAS Citarum sudah dilakukan lebih dari 20 kali, baik untuk tujuan riset maupun operasional pelayanan.

Sepanjang sejarah kegiatan modifikasi cuaca yang sudah dilakukan oleh UPT Hujan Buatan BPPT, hasil kegiatan umumnya selalu dievaluasi berdasarkan pendekatan aliran yang masuk ke dalam waduk (inflow) yang dihasilkan selama periode pelaksanaan kegiatan. Selama bertahuntahun, pola evaluasi seperti ini yang disepakati oleh UPT Hujan Buatan BPPT selaku penyedia jasa dengan para pengguna jasanya.

Bruintjes (1999) menyebutkan bahwa evaluasi hasil kegiatan modifikasi dapat dilakukan dalam dua metode pendekatan, yaitu secara statistik dan secara fisik. Salah satu evaluasi hasil kegiatan modifikasi secara statistik dengan menggunakan data curah hujan adalah penelitian yang dilakukan oleh Morisson etal (2009) untuk serangkaian kegiatan modifikasi cuaca yang dilakukan di Tasmania.
1 Peneliti pada UPT Hujan Buatan Badan Pengkajian dan Penerapan Teknologi, Indonesia

Gedung 1 BPPT Lantai 19, Jalan MH. Thamrin No. 8, Jakarta - Indonesia

Paper ini mencoba untuk membuat perhitungan penambahan curah hujan selama periode pelaksanaan kegiatan modifikasi cuaca di DAS Citarum sebagai bentuk lain dari sudut pandang evaluasi hasil kegiatan modifikasi cuaca dengan menggunakan pendekatan statistik. DAS Citarum dipilih sebagai lokasi studi berkaitan dengan jumlah frekuensi kegiatan modifikasi cuaca di daerah tersebut yang relatif banyak dan ketersediaan data historis yang relatif lebih lengkap dibandingkan dengan daerah lain di Indonesia yang juga pernah dilakukan kegiatan modifikasi cuaca.

Data curah hujan historis yang terkumpul sebagai bahan penyusunan paper ini hanya tersedia untuk daerah di sebelah barat DAS Citarum. Berdasarkan alasan tersebut, paper ini hanya melakukan analisis penambahan curah hujan hasil kegiatan modifikasi cuaca untuk periode kegiatan yang arah upwind-nya berasal dari arah baratan. DAS Cisadea dan Cimandiri di wilayah Sukabumi yang berada di sebelah barat daerah taget DAS Citarum ditentukan sebagai daerah kontrol tentatif (Gambar 1).

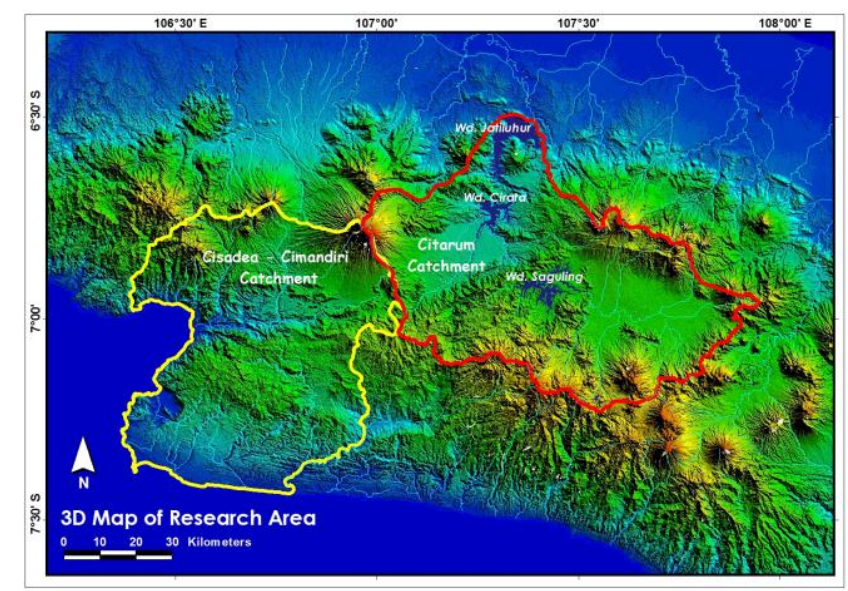

Gambar 1. Peta 3 Dimensi Lokasi DAS Citarum (Target) dan DAS Cisadea-Cimandiri di Wilayah Sukabumi (Kontrol)

Daerah kontrol merupakan suatu wilayah yang digunakan sebagai pembanding dalam memperkirakan peningkatan curah hujan di 
daerah target. Suatu wilayah dapat ditetapkan sebagai daerah kontrol, bila memenuhi persyaratan sebagai berikut : (1) berdekatan dengan daerah target; (2) berada di daerah up wind, (3) mempunyai tipe klimat yang sama dengan daerah target, (4) mempunyai tingkat korelasi ( $r$ ) curah hujan yang tinggi dengan daerah target dan (5) diharapkan tidak terkontaminasi oleh penyemaian awan.

\section{METODE DAN ANALISA}

\subsection{Analisis Prevailing Wind}

Dari sejumlah catatan kegiatan modifikasi yang pernah dilakukan di DAS Citarum sejak tahun 1980 - 2011, dilakukan analisis prevailing wind untuk mengetahui asal supply masa udara yang masuk ke daerah target. Hasil analisis prevailing wind menunjukkan bahwa umumnya supply masa udara saat kegiatan berasal dari arah baratan dan timuran. Pola angin di DAS Citarum secara temporal, selama bulan Desember hingga Maret adalah periode angin baratan, dan selanjutnya berubah menjadi angin timuran selama bulan April hingga November. Salah satu contoh hasil analisis prevailing wind saat kegiatan modifikasi cuaca (Maret 1988) disajikan pada Gambar 2.

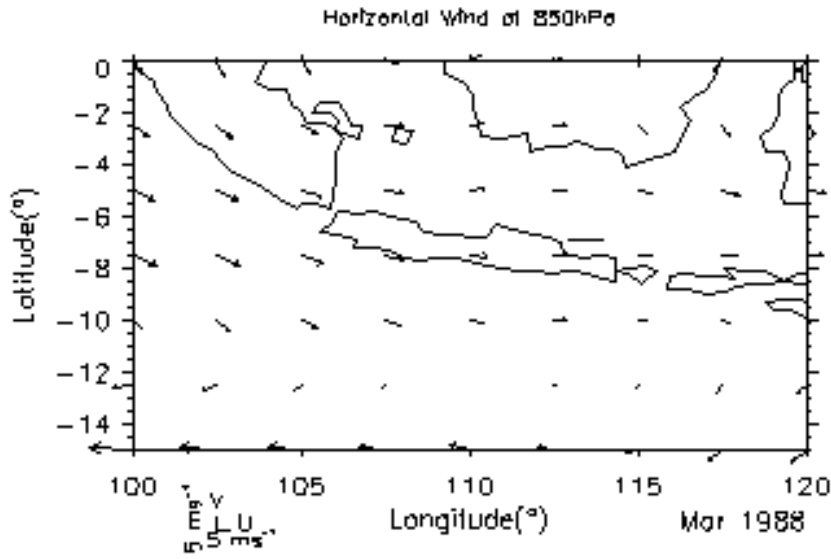

Gambar 2. Hasil analisis prevailing wind bulan Maret, 1988

\subsection{Uji Normalitas, Homogenitas dan Konsistensi Data Curah Hujan}

Untuk memastikan apakah wilayah Sukabumi sudah tepat dipilih sebagai daerah kontrol, dilakukan analisis data curah hujan untuk melihat kemiripan pola curah hujannya dengan daerah target. Analisis kemiripan pola curah hujan dilakukan dengan melakukan uji normalitas, uji homogenitas dan uji konsistensi terhadap data curah hujan di daerah kontrol dan daerah target. Panjang data curah hujan historis yang dianalisis adalah 25 tahun, periode tahun 1986 - 2010. Data curah hujan di daerah target dikumpulkan dari 11 lokasi stasiun hujan di dalam DAS Citarum (Bandung, Chincona, Cicalengka, Cililin, Ciparay, Cisondari, Montaya, Paseh, Saguling DAM, Sukawana dan Ujung Berung), sedangkan untuk daerah kontrol dikumpulkan dari 12 lokasi stasiun hujan di wilayah Sukabumi (Sukabumi, Salabintana, Batu Karut, Sukamaju, Geger Bitung, Cicurug, Pelabuhan Ratu, Cibodas, Cicatih, Cimandiri, Ciletuh dan PTP Goalpara).

Uji normalitas dilakukan untuk mengetahui normal tidaknya suatu distribusi data. Hal ini penting diketahui berkaitan dengan ketepatan pemilihan uji statistik yang akan digunakan. Dalam uji parametrik untuk analisis korelasi mensyaratkan bahwa data harus berdistribusi normal. Kenormalan data diketahui melalui sebaran data yang merata disetiap nilai. Metode yang digunakan untuk menguji kenormalan data adalah Metode Kolgomorov-Smirnov. Dalam hal ini pengujian normalitas data dengan menggunakan taraf $\alpha=5 \%$. Hasil uji normalitas data curah hujan di daerah target dan daerah kontrol memberikan nilai $p=0,200 \quad(>0,05)$, sehingga dapat disimpulkan bahwa data berasal dari populasi yang berdistribusi normal.

Pengujian homogenitas adalah pengujian mengenai sama tidaknya variansi-variansi dua buah distribusi atau lebih. Uji homogenitas dimaksudkan untuk memperlihatkan bahwa dua atau lebih kelompok data sampel berasal dari populasi yang memiliki variansi yang sama. Dari Hasil pengujian diperoleh nilai signifikansi sebesar $0,986(>0,05)$, sehingga dapat disimpulkan seluruh data curah hujan yang digunakan dalam penelitian adalah homogen.

Uji korelasi dimaksudkan untuk mengetahui adanya keeratan hubungan antara data sampel yang tekumpul pada kelompok daerah target dan daerah kontrol. Apabila dari masing-masing kelompok data mempunyai korelasi yang kuat, maka data yang terkumpul dapat dipercaya validitasnya dan reliabilitasnya (data konsisten). Hasil uji korelasi data memberikan nilai koefisien korelasi antara $\mathrm{CH}$ DAS Citarum dengan daerah kontrol di sekitarnya sebesar 0,915 ; artinya terdapat korelasi positif yang sangat kuat diantara hubungan data yang terkumpul pada daerah kontrol dan daerah target. Hasil uji korelasi pada taraf $\alpha=1 \%$ menunjukan bahwa nilai signifikansi kurang dari 0,01 , sehingga dapat disimpulkan bahwa kedua kelompok data tersebut berkorelasi sangat signifikan.

\subsection{Analisis Kemiripan Pola Curah Hujan}

Pada saat membandingkan data curah hujan daerah target dan kontrol secara time series, 
untuk bulan-bulan pada tahun tertentu dimana ada kegiatan modifikasi cuaca di DAS Citarum dihilangkan agar tidak terjadi bias dengan nilai pertambahan curah hujan yang terjadi di daerah target. Intensitas curah hujan bulanan di daerah target dan kontrol periode tahun 1986 - 2010 diperlihatkan dalam bentuk grafik pada Gambar 3. Dari Gambar 3 terlihat bahwa kondisi curah hujan antara kedua daerah tersebut mempunyai kemiripan dilihat dari pola fluktuatifnya dan secara umum intensitas curah hujan di daerah kontrol lebih tinggi dibandingkan daerah target.

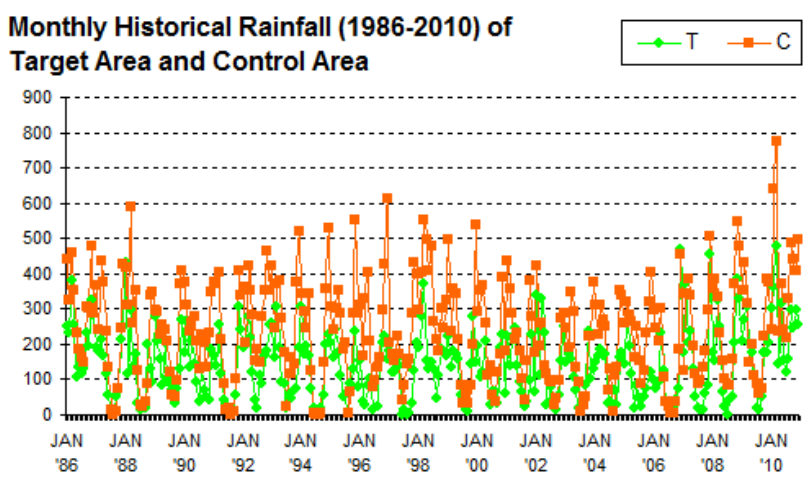

Gambar 3. Curah Hujan Historis Bulanan Daerah Target (T) dan Daerah Kontrol (K) Tahun 1986 2010

Kemiripan curah hujan di daerah target dan kontrol dibuktikan dengan analisis scatter, seperti tergambar pada Gambar 4. Berdasarkan hasil analisis, perbandingan curah hujan daerah target dan kontrol mempunyai nilai standar deviasi sebesar 133,69 dengan tingkat korelasi 0,77.

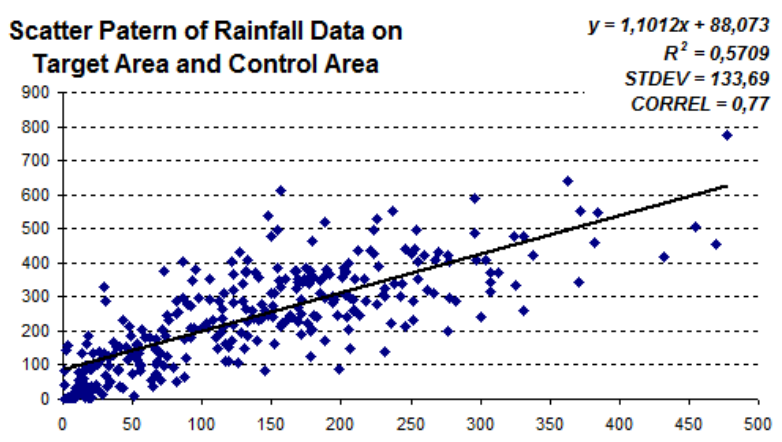

Gambar 4. Scattergram Curah Hujan Daerah Target (T) dan Daerah Kontrol (K)

Secara visual, kemiripan pola curah hujan di daerah kontrol dan target semakin jelas terlihat dari pola historis tahunannya (Gambar 5). Fluktuasi curah hujan dari bulan ke bulan di kedua daerah tersebut terlihat jelas mempunyai pola yang sangat mirip dan simetris.

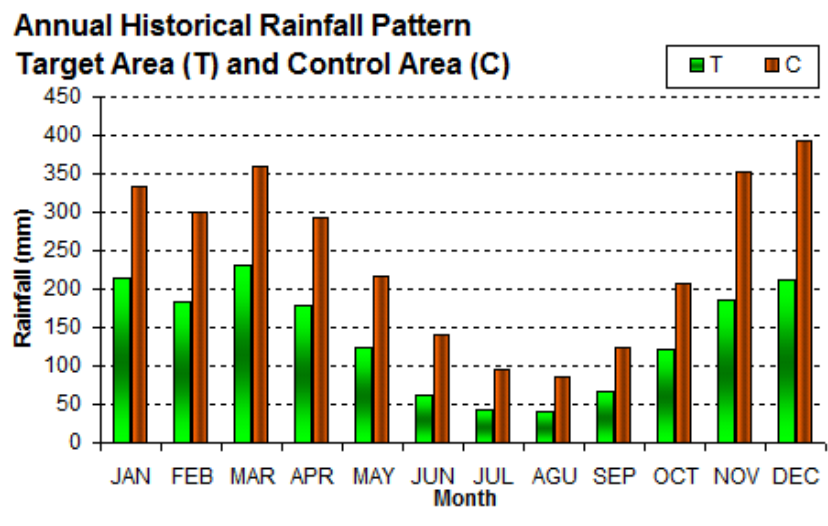

Gambar 5. Pola Curah Hujan Historis Tahunan di Daerah Target (T) dan Daerah Kontrol (K)

\subsection{Evaluasi Penambahan Curah Hujan Hasil Kegiatan Modifikasi Cuaca}

Nilai penambahan curah hujan hasil modifikasi cuaca di DAS Citarum yang dihitung dalam paper ini merupakan rerata hasil perhitungan dari 6 event kegiatan yang tersedia data curah hujan hariannya selama periode kegiatan berlangsung, yaitu periode kegiatan (1) 1 - 21 Maret 1988; (2) 1 - 24 Maret 1989; (3) 25 Maret - 23 April 1995; (4) 17 Pebruari - 18 Maret 1998; (5) 12 Maret - 10 April 2001; dan (6) 14 Pebruari - 15 Maret 2011.

Evaluasi penambahan curah hujan di daerah target dihitung dengan menggunakan 3 metode, yaitu (1) Metode Target Only, (2) Metode Target Kontrol, dan (3) Metode Double Ratio.

\subsubsection{Metode Target Only}

Metode Target Only dihitung dengan menggunakan data rerata historis sebagai dasar informasi perbandingan. Pengaruh penyemaian dan besarnya penambahan curah hujan dihitung dengan cara membandingkan curah hujan selang waktu tertentu di daerah target pada periode penyemaian dengan curah hujan historis pada selang waktu yang sama di daerah target tersebut. Perhitungan penambahan curah hujan menurut metode ini dihitung berdasarkan persamaan berikut :

$$
R=\frac{\mathrm{CH}_{a}-\mathrm{CH}_{s}}{\mathrm{CH}_{s}} \times 100 \% \cdots .(1)
$$

Dimana,

$R=$ = Tingkat pertambahan hujan (\%)

$\mathrm{CH}_{\mathrm{a}}=$ Jumlah curah hujan aktual di daerah target $(\mathrm{mm})$

$\mathrm{CH}_{s}=$ Rerata curah hujan historis di daerah target $(\mathrm{mm})$ 
Hasil perhitungan penambahan curah hujan dengan metode Target Only tersaji dalam Tabel 1. Dengan metode ini, dari kegiatan modifikasi cuaca tahun 1988, 1989 dan 2011 tidak tampak memberikan hasil penambahan curah hujan. Rerata nilai penambahan curah hujan hasil kegiatan modifikasi cuaca dari keenam perhitungan dengan menggunakan metode Target Only memberikan nilai sebesar $\mathbf{1 1 , 4} \%$.

Tabel 1. Hasil Perhitungan Penambahan Curah Hujan di DAS Citarum Dengan Metode Target Only

\begin{tabular}{|c|c|c|c|c|c|}
\hline No. & Period & Days & $\mathrm{CHa}(\mathrm{mm})$ & $\mathrm{CHs}(\mathrm{mm})$ & R (\%) \\
\hline 1 & $1-21 \mathrm{Mar} 1988$ & 21 & 149 & 201 & $-26,1$ \\
\hline 2 & $1-24$ Mar 1989 & 24 & 104 & 203 & $-48,8$ \\
\hline 3 & 25 Mar -23 Apr 1995 & 30 & 278 & 209 & 32,9 \\
\hline 4 & $17 \mathrm{Feb}-18 \mathrm{M}$ ar 1998 & 30 & 390 & 203 & 92,1 \\
\hline 5 & 12 Mar - 10 Apr 2001 & 30 & 318 & 195 & 63,3 \\
\hline 6 & $14 \mathrm{Feb}-15 \mathrm{M}$ ar 2011 & 30 & 114 & 208 & $-45,2$ \\
\hline \multicolumn{5}{|r|}{ Mean R (\%) } & 11,4 \\
\hline
\end{tabular}

\subsubsection{Metode Target Kontrol}

Dalam metode ini besarnya curah hujan pendugaan di daerah target saat ada penyemaian awan diperkirakan dari analisa regresi dengan menggunakan data curah hujan historis di daerah kontrol sebagai variabel bebas dan data curah hujan historis di daerah target untuk selang waktu yang sama. Curah hujan aktual selama selang waktu yang telah ditentukan diperoleh melalui pengukuran langsung. Curah hujan aktual ini merupakan curah hujan yang dipengaruhi oleh penyemaian awan. Berikut persamaannya :

$$
R=\frac{\mathrm{CH}_{a}-\mathrm{CH}_{s}}{\mathrm{CH}_{s}} \times 100 \%
$$

Dimana,

$R=$ Tingkat pertambahan hujan (\%)

$\mathrm{CH}_{a}=$ Curah hujan aktual di daerah target $(\mathrm{mm})$

$\mathrm{CH}_{s}=$ Curah hujan dugaan di daerah target yang diperoleh dari persamaan regresi $(\mathrm{mm})$

Hasil perhitungan penambahan curah hujan dengan metode Target Kontrol tersaji dalam Tabel 2. Dari metode ini, tidak terhitung adanya penambahan curah hujan selama periode kegiatan penyemaian awan.

Tabel 2. Hasil Perhitungan Penambahan Curah Hujan di DAS Citarum Dengan Metode Target Kontrol

\begin{tabular}{|c|c|c|c|c|c|c|}
\hline No. & Period & Days & $\mathrm{CHa}(\mathrm{mm})$ & $y=a x+b$ & $\mathrm{CHs}(\mathrm{mm})$ & $R(\%)$ \\
\hline 1 & $1-21$ Mar 1988 & 21 & 149 & $y=0,1117 x+312,74$ & 329 & $-54,9$ \\
\hline 2 & $1-24$ Mar 1989 & 24 & 104 & $y=0,0192 x+124,11$ & 126 & $-17,6$ \\
\hline 3 & 25 Mar - 23 Apr 1995 & 30 & 278 & $y=0,9224 x+149,22$ & 405 & $-31,5$ \\
\hline 4 & 17 Feb - 18 Mar 1998 & 30 & 390 & $y=0,8248 x+152,67$ & 474 & $-17,8$ \\
\hline 5 & 12 Mar - 10 Apr 2001 & 30 & 318 & $y=-3,2629 x+366,09$ & -673 & $-147,3$ \\
\hline 6 & $14 \mathrm{Feb}-15 \mathrm{Mar} 2011$ & 30 & 114 & $y=1,0068 x+120,37$ & 235 & $-51,5$ \\
\hline \multicolumn{6}{|r|}{ Mean R \%) } & $.53,4$ \\
\hline
\end{tabular}

\subsubsection{Metode Double Ratio}

Analisis double ratio adalah analisis yang membandingkan antara rasio jumlah curah hujan daerah target terhadap daerah kontrol pada periode penyemaian awan, dengan rasio jumlah curah hujan daerah target terhadap kontrol pada periode tanpa penyemaian awan. Pendekatan dengan data historis dilakukan dengan 2 cara, yaitu dengan data historis normal (1986 - 2009) dan data historis yang distratifikasi.

Nilai double ratio dihitung dengan persamaan sebagai berikut :

$$
R=\frac{T s / C s}{T u s / C u t s}(3)
$$

Dimana ,

$R=$ Nilai "Double Ratio"

$(T / C) s=$ Perbandingan antara curah hujan aktual di daerah target pada selang waktu penyemaian awan, dengan curah hujan daerah kontrol pada selang waktu yang sama.

$(T / C)$ us $=$ Perbandingan curah hujan di daerah target dan kontrol pada selang waktu tidak ada penyemaian awan.

Peningkatan curah hujan akibat penyemaian dapat dihitung dengan persamaan sebagai berikut

$$
R \%=(D R-1) \times 100 \% \ldots(4)
$$

Hasil perhitungan penambahan curah hujan dengan metode Double Ratio tersaji dalam Tabel 3. Dengan metode ini, dari kegiatan modifikasi cuaca tahun 1989 dan 2011 tidak tampak memberikan hasil penambahan curah hujan. Rerata nilai penambahan curah hujan hasil kegiatan modifikasi cuaca dari keenam perhitungan dengan menggunakan metode Double Ratio memberikan nilai sebesar $\mathbf{8 5 , 0} \%$.

Tabel 3. Hasil Perhitungan Penambahan Curah Hujan di DAS Citarum Dengan Metode Double Ratio

\begin{tabular}{|r|c|c|c|c|c|c|c|c|}
\hline No. & Period & Days & Ts & Cs & Tus & Cus & DR & R (\%) \\
\hline 1 & 1 - 21 Mar 1988 & 21 & 149 & 201 & 172 & 347 & 1,5 & 49,4 \\
\hline 2 & 1 - 24 Mar 1989 & 24 & 104 & 203 & 230 & 347 & 0,8 & $-22,8$ \\
\hline 3 & 25 Mar - 23 Apr 1995 & 30 & 278 & 209 & 221 & 347 & 2,1 & 108,9 \\
\hline 4 & 17 Feb - 18 Mar 1998 & 30 & 390 & 203 & 191 & 300 & 3,0 & 202,0 \\
\hline 5 & 12 Mar - 10 Apr 2001 & 30 & 318 & 195 & 189 & 331 & 2,9 & 185,9 \\
\hline 6 & 14 Feb - 15 Mar 2011 & 30 & 114 & 208 & 205 & 323 & 0,9 & $-13,6$ \\
\hline \multicolumn{19}{|c|}{ Mean R \%) } & 85,0 \\
\hline
\end{tabular}

\section{PENUTUP}

Nilai penambahan curah hujan kegiatan modifikasi cuaca di DAS Citarum dari hasil penelitian ini dirasakan oleh Penulis masih belum memberikan nilai secara komprehensif, karena untuk daerah kontrol di sebelah timur belum 
disertakan dalam analisis karena belum tersedia datanya. Oleh karena itu, penelitian ini masih akan dilanjutkan dengan melakukan perhitungan yang sama dengan menggunakan daerah kontrol di sebelah timur DAS Citarum.

Satu fenomena menarik didapat dari hasil penelitian ini, yaitu diketahui bahwa kondisi curah hujan di daerah Sukabumi secara tahunan selalu lebih tinggi dibandingkan DAS Citarum, tidak terpengaruh arah pola angin secara musiman. Kiranya fenomena ini dapat menjadi suatu topik penelitian baru yang bisa ditujukan untuk mengetahui faktor apa yang menyebabkan fenomena yang demikian.

\section{REFERENSI}

Roeloef T. Bruintjes. 1999. A Review of Cloud Seeding Experiments to Enhance Precipitation and Some New Prospects. Bulletin of the American Meteorological Society. Vol. 80, No. 5, May 1999.

Anthony E. Morrison, Steven T. Siems, And Michael J. Manton. 2009. On the Analysis of a Cloud Seeding Dataset over Tasmania. Journal Of Applied Meteorology And Climatology, Volume 48, June 2009.

UPT Hujan Buatan BPPT. 1995. Laporan Kegiatan Penyemaian Awan di DAS Citarum Tahun 1991. 